\title{
BEYOND NEOPLATONISM: \\ LOVE IN THE POETRY OF FRANCISCO DE ALDANA
}

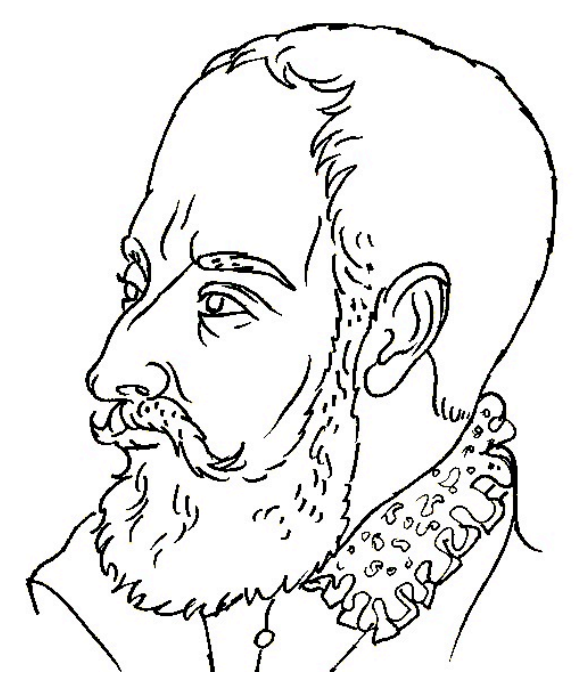

\author{
Paul Joseph Lennon \\ Trinity Hall \\ University of Cambridge
}

A thesis submitted in fulfilment of the requirements for the degree of

Doctor of Philosophy at the University of Cambridge.

August 2013 


\section{Declaration}

I declare that, except where otherwise stated, this thesis is the result of my own work and includes nothing that is the outcome of work done in collaboration. No part of this thesis has been submitted to the University of Cambridge, or elsewhere, for a degree or any other qualification. Finally, I declare that this dissertation does not exceed the prescribed word limit.

Name: Paul Joseph Lennon

Signature:

Date: 


\section{Summary}

Francisco de Aldana (c. 1540-78) is an oft-neglected warrior-poet of the Spanish Golden Age. His poetry was influenced by his Florentine education in classics and earned him praise from the likes of Cervantes, Lope de Vega, and Quevedo. Over the course of four chapters I will explore Aldana's approach to love, which is unique in its synthesis of the seemingly opposing and discordant elements of Neoplatonic spirituality and sensual physicality. This unusual combination is considered in light of Ausiàs March's incorporation of physicality, as well as Boscán's reintroduction of aurea mediocritas to ensure a happy marriage, which together help highlight the originality of Aldana's contribution to love lyric in Renaissance Spain. Aldana is seen to favour a love that recognises the importance of the body in spiritual transcendence, in accordance with Plato's Symposium. Shared transcendental moments are considered possible but remain fleeting and death is the only way to permanently abandon the physical realm and seek unity with God.

Aldana's Neoplatonic influences are charted from Ficino's De amore (1484) and extend to those later texts that moved away from the Ficinian model, namely; Bembo's Gli Asolani (1484), Castiglione's Il cortegiano (1528), Ebreo's Dialoghi d'amore (1535), Tullia D'Aragona's Dialogo dell'infinità d'amore (1547), and Nifo's De pulchro et amore (1549). Lucretius' De rerum natura, the elegies of Propertius, and the writings of Ovid on love form the basis of the classical influences from which Aldana, often through their combination with Petrarchan staples, fashions startling examples of sensual physicality that go beyond the limits of contemporary descriptions of the body and the act of love making.

The poems selected from Aldana's corpus are grouped thematically. Chapter One considers fragments of philosophical, religious, and epistolary poetry that frame his approach to love. Chapter Two centres on a rare example of reciprocal love that incorporates the figure of seafaring. Chapter Three considers how Aldana's pastoral texts deconstruct their own idealised nature and invite the reader to consider love outside the artificial realm. This is partly achieved by his incorporation of the sonetto dialogato tradition. Chapter Four, on the mythological genre, concerns love as a neutral, universal force shaped by those it affects. This is illustrated via two pairings: one divine, one mortal. The divine couple highlights love's potential to render both positive and sinister effects, while the mortal one illustrates the successful synthesis of spiritual and physical components to produce a love unique to Aldana's poetic corpus. 


\section{Acknowledgements}

Innumerable thanks go to my supervisor, the indefatigable Dr Rodrigo Cacho Casal, who first introduced me to the poetry of Francisco de Aldana. His expertise, dedication, and guidance throughout the process of my researching and writing this thesis have been invaluable.

My thanks also go to Dr Anne Holloway for being a continued source of advice and encouragement.

I would like to extend my appreciation to the Arts \& Humanities Research Council, whose funding made it possible for me to undertake this project in the first instance.

For the support given by my friends and family, in particular my parents Frank and Rosemary, I fear thank you would not be enough. To them I gratefully dedicate this thesis. 


\section{Contents}

Declaration

Summary

Acknowledgements

Introduction

1. The essence of love 6

Neoplatonism $r$

$\begin{array}{ll}\text { Petrarchism } & 14\end{array}$

$\begin{array}{ll}\text { Contemporary debate } & 17\end{array}$

$\begin{array}{lr}\text { Aldana's endeavour } & 26\end{array}$

Conclusion $\quad 40$

2. The temerity to love 42

The dama in Aldana 46

Love, the gods, and mankind $\quad 55$

Navigating the storm $\quad 68$

$\begin{array}{ll}\text { Conclusion } & 74\end{array}$

3. The birds and the bees 76

Pastoral polemics $\quad 83$

Deconstructing the ideal 95

$\begin{array}{lr}\text { Conclusion } & 105\end{array}$

4. The oldest myth 108

Medoro y Angélica 111

Venus and Mars 129

Conclusion 144

$\begin{array}{ll}\text { Conclusion } & 147\end{array}$

Bibliography 156 